\title{
Inflammatory mechanisms in the lung
}

\author{
B Moldoveanu' \\ P Otmishi' \\ $P$ Jani' \\ J Walker ${ }^{1,2}$ \\ X Sarmiento ${ }^{3}$ \\ J Guardiola' \\ M Saad' \\ Jerry Yu'
}

'Department of Medicine, University of Louisville, Louisville, KY, USA, 40292; ' ${ }^{2}$ epartment of Respiratory Therapy, Bellarmine University, Louisville, KY, USA, 40205; Intensive Care Medicine Service, University Hospital Germans Trias i Pujol, Badalona, Spain 08916
Correspondence: Jerry Yu

Department of Medicine (Pulmonary),

University of Louisville, ACB-3, 550

S. Jackson St. Louisville, KY 40292, USA

Tel +l $5028525 \mid 46$

Fax +I 5028521359

Email j0yu000।@louisville.edu

\begin{abstract}
Inflammation is the body's response to insults, which include infection, trauma, and hypersensitivity. The inflammatory response is complex and involves a variety of mechanisms to defend against pathogens and repair tissue. In the lung, inflammation is usually caused by pathogens or by exposure to toxins, pollutants, irritants, and allergens. During inflammation, numerous types of inflammatory cells are activated. Each releases cytokines and mediators to modify activities of other inflammatory cells. Orchestration of these cells and molecules leads to progression of inflammation. Clinically, acute inflammation is seen in pneumonia and acute respiratory distress syndrome (ARDS), whereas chronic inflammation is represented by asthma and chronic obstructive pulmonary disease (COPD). Because the lung is a vital organ for gas exchange, excessive inflammation can be life threatening. Because the lung is constantly exposed to harmful pathogens, an immediate and intense defense action (mainly inflammation) is required to eliminate the invaders as early as possible. A delicate balance between inflammation and anti-inflammation is essential for lung homeostasis. A full understanding of the underlying mechanisms is vital in the treatment of patients with lung inflammation. This review focuses on cellular and molecular aspects of lung inflammation during acute and chronic inflammatory states.
\end{abstract}

Keywords: inflammation, lung, inflammatory mediators, cytokines

\section{Introduction}

Immunity involves innate and adaptive systems. Innate immunity is nonspecific and evokes rapid responses, including inflammation in face of pathogen insults. Adaptive immunity is antigen-specific. It first detects the specific antigen and then mobilizes inflammatory cells to target that particular antigen. The innate and adaptive systems share components and act in concert to defend against pathogens. The lungs are exposed to constant insults from the atmosphere and also to toxic molecules circulating through the pulmonary and bronchial vasculature. Elaborate pulmonary defense mechanisms are needed for survival. These include first-line filtration and removal systems such as the nasal vibrissae, mucociliary escalator, and cough reflex. Secretory immunoglobulin A (IgA) in mucus and surfactant produced by alveolar cells also assist in immunity against pathogens and smaller particles, while resident immune cells within the lung parenchyma await organisms that successfully penetrate the physical barriers. Optimal lung defense requires the coordinated action of multiple cell types.

\section{Defense mechanisms in the lung}

The airway epithelium is the first site of contact with inhaled agents. Its epithelial cells secrete a variety of substances such as mucins, defensins, lysozyme, lactoferrin. and nitric oxide, which nonspecifically shield the respiratory tract from microbial attack. ${ }^{1}$ The epithelial cells also produce a number of mediators such as reactive oxygen radicals, cytokines (TNF- $\alpha$, IL-1 $\beta$, granulocyte/macrophage colony-stimulating factor [GM-CSF]), and platelet-activating factor to recruit inflammatory cells onto the site of inflammation. ${ }^{2}$ The cytokines stimulate arachidonic acid release from membrane lipids, 
leading to production of eiconasoids, which further stimulate mucus secretion by goblet cells and tissue inflammation.

Surfactant lies on the surface of alveoli and contains four surfactant proteins (SP A-D). Important for reducing lung surface tension, these proteins play a critical role in surfactant absorption into the alveolar surface. SP-A and SP-D also participate in host defense. They bind bacterial surface molecules, modulate leukocyte activity, and lead to pathogen opsonization. ${ }^{3}$

IgA secreted by plasma cells forms an additional epithelial protective barrier, which prevents microbial adherence to the epithelial surface ${ }^{4}$ and inhibits certain viral infections (influenza and rotavirus) by interfering with their assembling processes. It also binds to pathogens, causing phagocytosis and antibody-dependent cell-mediated cytotoxicity. Selective IgA deficiency manifests as atopy and recurrent respiratory tract infections. Moreover, patients with COPD have decreased IgA levels in saliva and bronchial secretions. ${ }^{5}$ Immunoglobulin $\mathrm{E}$ (IgE) induces immediate type hypersensitivity in the respiratory tract. It produces severe reactions by binding to IgE receptors on the surfaces of mast cells, basophils, eosinophils, and B lymphocytes. Repeat exposure to the same antigen induces degranulation and the release of pro-inflammatory mediators, including histamine, prostaglandins, leukotrienes, and tryptase. ${ }^{6}$ These increase vascular permeability, bronchoconstriction, and inflammatory cell infiltration.

The foregoing pulmonary defenses maintain sterility in the lower respiratory tract, and redundancy in their mechanisms ensures overlapping protection from invading pathogens.

\section{Inflammatory cells}

Dendritic cells are antigen-presenting cells (APCs), which stimulate naïve $\mathrm{T}$ cell proliferation. Dendritic cells and macrophages are the first line of defense in recognizing various pathogens. Originating in bone marrow, dendritic cells reach tissues through blood circulation and, in the lung, reside in and below the airway epithelium, the alveolar septa, pulmonary capillaries, and airway spaces. ${ }^{7}$ Once the dendritic cell identifies, ingests, and processes an antigen, it migrates to the lymph nodes and presents the antigen to resident $\mathrm{T}$ cells, inducing the immune response.

Macrophages reside in the airways, alveoli, and lung interstitium, or migrate into the lung microvasculature. Their role is essential in modulating acute and chronic inflammatory responses, but although macrophages can proliferate within the lung, their number is not adequate to fight infection. ${ }^{8}$ Macrophage function is augmented by dendritic cells. Together they are capable of phagocytosing bacteria, particulates, and apoptotic cells. However, macrophages are the main source of cytokines, chemokines, and other inflammatory mediators that propagate or suppress the immune response. Following an insult, macrophages and epithelial cells secrete chemokines and cytokines, promoting neutrophil accumulation and local inflammation. ${ }^{9}$

Neutrophils provide second-line defense. They are the first cells to be recruited to sites of infection or injury, and attack fungi, protozoa, bacteria, viruses, and tumor cells. During pulmonary infection, neutrophils migrate out of the pulmonary capillaries and into the air spaces. ${ }^{10}$ After phagocytosis, neutrophils kill ingested microbes with reactive oxygen species, antimicrobial proteins (bactericidal permeability-inducing protein and lactoferrin), and degradative enzymes (elastase). Deficits in neutrophil quantity (neutropenia) and quality (chronic granulomatous disease) predispose patients to opportunistic lung infections.

Lymphocytes are found throughout the airway and lung parenchyma. There are two major populations of lymphocytes: thymus-dependent $\mathrm{T}$ cells and bone marrowdependent B cells. T lymphocytes provide cell-mediated immunity, while B lymphocytes produce humoral immune responses by synthesizing antibodies (immunoglobulins). T lymphocytes have two major subsets: CD4+ and CD8+. CD4+ T lymphocytes are also known as helper $\mathrm{T}$ cells, which are further subdivided into Th1 and Th2, with different cytokine profiles. Th1 cells drive cellular immunity. Th1 cytokines (interferon gamma, TNF- $\alpha$ ) produce the pro-inflammatory responses to fight viruses and other intracellular parasites, and to eliminate cancer cells. Excessive pro-inflammatory responses can lead to uncontrolled tissue damage. Th2 cells drive humoral immunity to up regulate antibody production to fight extracellular organisms. Th2 cytokines (IL-4, IL-5, IL-9, and IL-13) promote IgE and eosinophilic responses in atopy. Excessive Th2 responses will counteract the Th1-mediated anti-microbial actions (Figure 1). Optimally, a balanced Th1 and Th2 response is suited to the immune challenge, and a dysregulated response is linked to a variety of chronic inflammatory conditions like asthma and chronic bronchitis. ${ }^{11} \mathrm{CD} 8+\mathrm{T}$ cells are mainly cytotoxic $\mathrm{T}$ cells. They secrete molecules that kill infected cells and tumor cells. In addition, there is a natural killer cell (NK cell) subset of T cells with no antigen-specific receptors. ${ }^{12}$ Another subset of T cells, named NKT cells, which have the properties of NK cells, are important in combating 


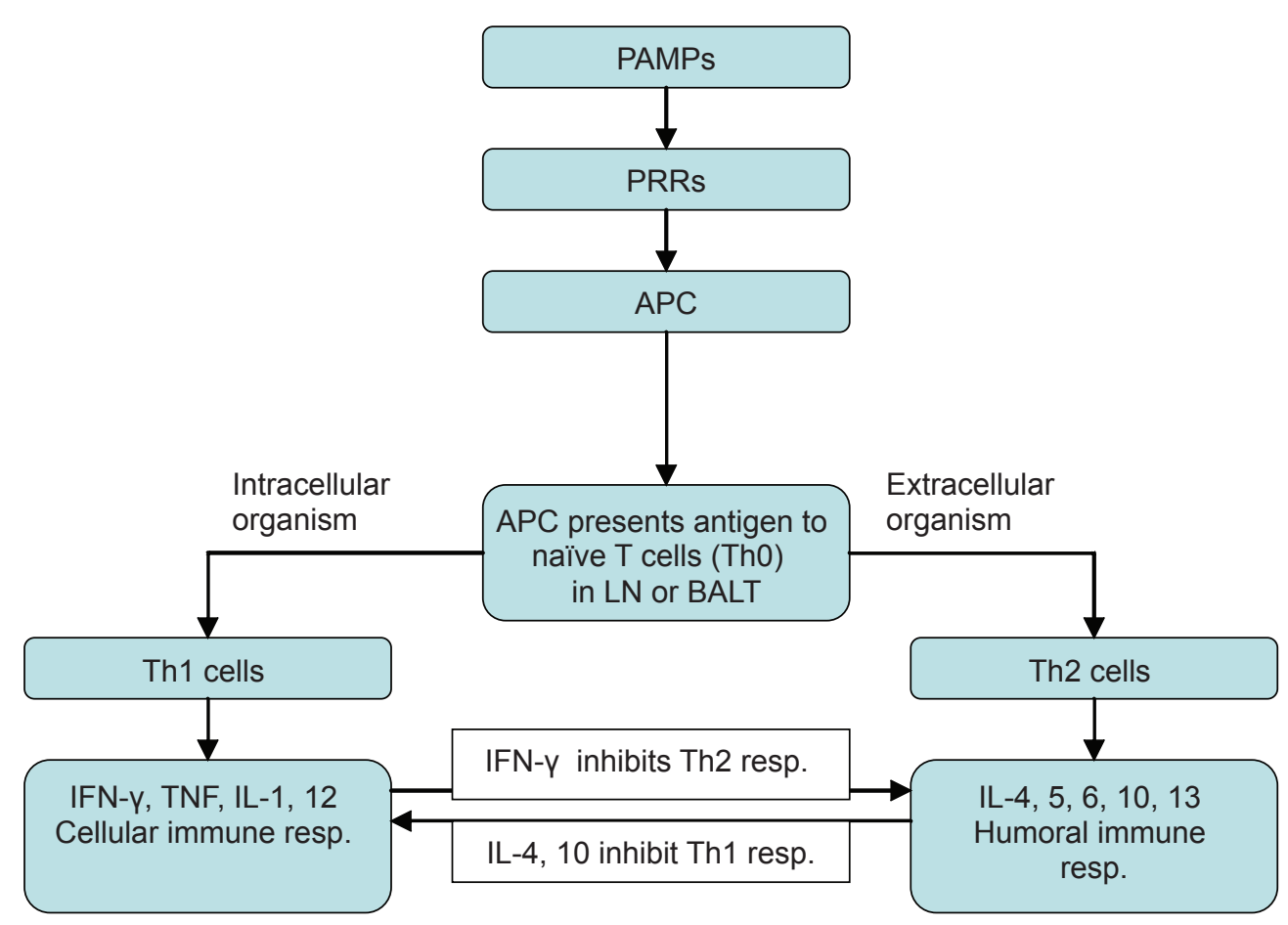

Figure I Immune response to lung infections.

Abbreviations: APC, antigen presenting cell; BALT, bronchial-associated lymphoid tissues; LN, lymph nodes; PAMPs, pathogen-associated molecular patterns; PRRs, pattern recognition receptors; resp, response; Th0, naïve T cells; ThI, type I helper T cells, Th2 cells, type 2 helper T cells.

bacteria, protozoa, and viruses. ${ }^{13}$ Furthermore, there are regulatory $\mathrm{T}$ cells, which suppress the other lymphocytes. During the immune response, some antigen-activated B cells and $\mathrm{T}$ cells differentiate into memory cells, producing longlasting immunity.

Mast cells reside near blood vessels and nerves in tissues throughout the body. They may be activated by a variety of stimuli through various receptors. In the airways, mast cells have receptors for IgE. Once activated, the mast cells produce histamine, leukotrienes, proteases, cytokines, chemokines, and other substances that cause immediate airway inflammation, leading to asthma symptoms. Secreted cytokine and chemokine may contribute to chronic airway inflammation. Mast cells function in innate immunity, host defense against parasites, tissue repair, and

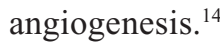

Eosinophils, the least common white blood cells, are often associated with parasite infections, allergic diseases (such as asthma), chronic lung inflammatory states, and hypereosinophilic syndrome. The eosinophil is an important source of major basic proteins, lipid mediators, cytokines, and growth factors, and also secretes mast cell stem cell factor, essential for mast cell growth, activation, chemotaxis, and degranulation. ${ }^{15}$
Although the inflammatory cells take center stage, epithelial, endothelial and mesenchymal cells also participate in the inflammatory process. . $^{2,16}$

\section{Cytokines}

Cytokines are secreted polypeptides produced by all kinds of cells. They have autocrine, paracrine, or endocrine functions to regulate immunity and inflammation. Binding to specific membrane receptors, cytokines signal the cell via secondary messengers, increasing or decreasing expression of membrane proteins, as well as cell proliferation and secretion. Different cell types can secrete the same cytokine and a given cytokine can act on several cell types (pleiotropy) to stimulate or suppress other cytokines. Cytokines that act as chemotactic agents or chemoattractants for other cells are known as chemokines. Cytokines are redundant, that is, similar functions can be produced by different cytokines that act either synergistically or antagonistically.

Cytokines can be categorized as pro-inflammatory or antiinflammatory. Major pro-inflammatory cytokines are TNF- $\alpha$, IL-1 $\beta$, IL-6, IL- 8 , and IFN $\gamma$. They activate the immune system and participate in the acute inflammatory response. TNF- $\alpha$ and IL- $1 \beta$ are the most important pro-inflammatory 
cytokines and stimulate antigen presentation, adhesion molecule expression on endothelial cells, inflammatory cell activity, and expression of matrix-degrading enzymes, like collagenase. Major anti-inflammatory cytokines include IL-10, TGF- $\beta$, and IL-1 ra (a natural IL-1 receptor antagonist). Alveolar macrophages secrete the anti-inflammatory cytokines to down regulate the inflammatory response in the lungs. ${ }^{17,18}$ Receptors for TGF- $\beta$ are present on virtually all cells. TGF promotes wound healing and scar formation. IL-10 inhibits the production of pro-inflammatory cytokines by $\mathrm{T}$ cells, NK cells, and monocytes. ${ }^{19}$ Increasing evidence indicates that dysregulation of cytokines is an important step in many pulmonary diseases. For example, allergens stimulate Th2 cells. In allergic asthma, APCs activate Th2 cells to produce IL-4 and IL-13, which in turn stimulate B cells to produce $\operatorname{IgE}$ and subsequent mast cell degranulation. Activation of Th2 cells also causes IL-5 production, which stimulates eosinophils. ${ }^{20}$ Mediators released by mast cells and eosinophils produce an asthmatic attack. Many cytokines are associated with COPD, including TNF- $\alpha$, IFN- $\gamma$, IL-1 $\beta$, IL-6, and GM-CSF. ${ }^{21}$ In ARDS, pro-inflammatory cytokines (TNF- $\alpha$ and IL-1 $\beta$ ) are increased ${ }^{22}$ and the increment of anti-inflammatory cytokines like IL-10 may not keep up with their production. It has been reported that IL-10 is lower in ARDS than in critically ill non-ARDS patients. ${ }^{23}$ The imbalance of the pro- and anti-inflammatory cytokines may promote the disease.

\section{Acute pulmonary inflammation}

Macroscopically, inflammation is characterized by redness, swelling, heat, pain, and loss of function. Microscopically, it is exhibited by vasodilation, increased vascular permeability, and inflammatory cell infiltration. Inflammatory responses are to destroy and remove, as well as to wall off and confine the injurious agents. Furthermore, inflammation stimulates the immune response to promote recovery. Acute lung inflammation is dominated by neutrophils, whereas chronic reactions involve mainly macrophages and lymphocytes. ARDS is an example of acute inflammation not only persisting but also becoming amplified to involve the entire organ. During acute lung insult, endothelial cells are activated to express chemotactic factors, including endothelial-derived adhesion molecules that lead to attachment and diapedesis of leukocytes in the region. A resulting chemotactic gradient first directs neutrophil migration and then further chemokine production to orchestrate formation of granulation tissue comprising cellular matrix, fibroblasts, endothelial cells, and leukocytes.

\section{Bacterial infections}

When the lung is exposed to minimal bacterial loads, pathogen clearance operates through innate defenses and the event is generally subclinical. Acute infection results when higher loads of bacteria overcome the local defenses, leading to acute inflammation involving both innate and adaptive defenses. Bacterial colonization results from abnormal innate defenses, establishing an equilibrium between bacterial replication and clearance. Chronic infection occurs when marked a inflammatory response generated by host defense mechanisms fails to clear the bacteria, with continued tissue destruction. $^{24}$

When inhaled in a significant load, bacteria overcome primary host defenses by releasing ciliary toxins, pneumolysin, endotoxin, and IgA proteases, thereby disrupting mucociliary clearance. ${ }^{25}$ Ultimately, bacteria adhere to the epithelium. In response, dendritic cells, alveolar macrophages, and epithelial cells are activated as pathogen markers are identified through toll like receptors (TLRs). Recognition of the pathogen initiates inflammation, which progresses through four phases: initiation, amplification, phagocytosis, and resolution.

\section{Initiation}

TLRs are membrane-bound pattern-recognition receptors (PRRs). They recognize specific conserved molecular patterns broadly shared by pathogens, known as pathogen-associated molecular patterns (PAMPs). PAMPs are molecules essential for microorganism survival, and innate and adaptive immunity ensue when they are engaged by PRRs. ${ }^{4}$ There are at least 10 types of TLRs that recognize microbes on the cell surface or in endosomes. TLR-4 recognizes endotoxins and lipopolysaccharide-binding proteins from gram-negative bacteria; TLR-2 recognizes gram-positive bacteria and peptidoglycans. ${ }^{26}$ In addition, cytosolic PRRs consist mainly of nucleotide oligomerization domain (NOD)-like receptors (NLRs) and function as regulators of innate immune response against microbial pathogens. Stimulation of NOD1 and NOD2, two prototypic NLRs, activates mitogen-activated protein kinases and NF- $\kappa \mathrm{B} .{ }^{27}$ The NLRs recognize specific components of bacteria and form a cytoplasmic signaling complex with other proteins known as the inflammasome. ${ }^{28}$ In some cells, inflammasome activation may lead to rapid host cell death (pyroptosis), which may protect the host by preventing bacterial replication.

\section{Amplification}

After PAMPs are recognized, cell activation increases transcription factors like NF- $\kappa \beta$, producing growth factors, 
chemokines, adhesion molecules and pro-inflammatory cytokines including IL- 8 and TNF- $\alpha .{ }^{29}$ IL- 8 acts as a neutrophil chemotactic agent, and TNF- $\alpha$ increases expression of lung capillary endothelial cell adhesion molecules ${ }^{30}$ for increased neutrophil adhesion. Activated neutrophils release more IL- $8,{ }^{31}$ which in turn increases neutrophil recruitment. Also, elastase from activated neutrophils induces epithelial IL-8 production. ${ }^{32}$ While neutrophils and alveolar macrophages are combating the pathogen in a nonspecific way, dendritic cells present the $\mathrm{T}$ lymphocytes with the foreign antigen and cause either a Th1 or Th2 response. The activated $\mathrm{T}$ cells and $\mathrm{B}$ cells (producing antibodies) follow to defend the body against the bacterial attack. Growth factors and cytokines released from activated $\mathrm{T}$ cells further stimulate the macrophages.

\section{Phagocytosis}

After successfully evading mechanical barriers and ciliary removal, and surviving the actions of surfactants and antibodies, bacteria may encounter complement proteins. Complements facilitate recognition by alveolar macrophages of bacteria through PRRs and prepare bacteria for phagocytosis. At least two additional mechanisms can be activated to enhance killing and clearance of the microbe. ${ }^{33}$ The first involves alveolar macrophages and their ability to liberate chemotactic factors that attract nearby neutrophils and initiate inflammatory responses. The second occurs when the bacteria trigger $\mathrm{T}$ cells, to release cytokines that stimulate the phagocytic and bactericidal capacity of alveolar macrophages.

\section{Resolution}

Resolution occurs after a successful host response. Complete bacterial phagocytosis, and killing by reactive oxygen species, bacteriocidal permeability-inducing protein, lactoferrin, elastase, and neutrophil extracellular trap, ${ }^{34}$ down regulates the host defense system. Resolving lung inflammation depends upon apoptosis as well as timely and adequate removal of acute inflammatory cells by macrophages. During apoptosis, neutrophils and eosinophils undergo surface changes enabling phagocytes to recognize and ingest them. The apoptotic process is modulated through extracellular signaling. For example, neutrophils cultured in the bronchial alveolar lavage fluid from ARDS patients have a longer lifespan than those from patients with normal lungs. Pro-inflammatory cytokines such as GM-CSF may be responsible for apoptosis delay. ${ }^{35} \mathrm{In}$ some circumstances, apoptosis of eosinophils and neutrophils is conversely regulated. For example, dexamethasone enhances apoptosis of eosinophils, but inhibits that of neutrophils, prolonging neutrophil viability. ${ }^{5}$ Resolution of inflammation not only depends on the removal of apoptotic cells but also on suppression of inflammatory mediator production. ${ }^{6}$ Incomplete resolution leads to chronic inflammation.

\section{Viral infections}

Viruses activate the innate immune system through cell surface and cytosolic PRRs, which detect viral components (especially nucleic acids). TLR-3 recognizes double-stranded RNA viruses, while TLR-7 and TLR-8 detect single-stranded RNA viruses. The activated immune cells synthesize antiviral type I interferon (IFN), pro-inflammatory cytokines, and chemokines including TNF- $\alpha$, IL-1 $\beta$, IL-6, IL-8, IL-12, and monocyte chemoattractant protein $1 .{ }^{36}$

Respiratory virus infections elicit primarily a Th1 type response, which is dominated by IFN $\gamma$ production. Th2 responses are ineffective or even detrimental. ${ }^{37} \mathrm{CD} 8+$ cytotoxic $\mathrm{T}$ cells as well as NK cells play a key role in viral clearance, although neutralizing antibody is also generated late in a primary infection by influenza and parainfluenza. ${ }^{37}$ In a secondary infection, both CD4+ and CD8+ T cells respond promptly. Large populations of memory $\mathrm{T}$ cells persist in the airways and lung parenchyma and decrease gradually over several months, and then stabilize at a low level. This progressive loss correlates with a decline in protective cellular immunity, suggesting a critical role of memory $\mathrm{T}$ cells in the lung. Viruses are also responsible for episodes of exacerbations of COPD and asthma, where they increase the airway inflammation (acute exacerbation or chronic inflammation).

\section{Parasitic infections}

Many protozoa and helminthes involve the respiratory system. Our understanding of the role of TLR in parasitic diseases is just beginning. For example, TLR-2 and TLR-9 are associated with malarial infection, ${ }^{38}$ whereas TLR-4 involves containment of leishmaniasis. ${ }^{39}$ Protozoa vary greatly and stimulate distinct immune responses. Protozoa may be phagocytized by macrophages, but many are resistant and may replicate within macrophages. ${ }^{40}$ In resolving Leishmania infections, a protective Th1 response by host cells leads to macrophage activation to kill the organism. ${ }^{41}$ PRRs are also used to detect molecules on protozoa, which leads to their killing by complement activation and phagocytosis. ${ }^{42}$

Helminthes usually produce $\mathrm{Th} 2$ responses, with secretion of IgE and activation of eosinophils, basophils, and mast cells. In contrast, bacteria and viruses typically evoke IFN $\gamma$ dominant Th1 response with activation of CD8+ cytotoxic T cells, neutrophils, and macrophages. Activated macrophages engulf 
and destroy microorganisms through expression of inducible nitric oxide synthesis (iNOS). However, in Th2 response to helminthes, macrophage activation is triggered by IL-4, IL-10, IL-13, and IL-21, and does not express iNOS. ${ }^{43}$ The activated macrophages and eosinophils may contribute to the healing of damaged tissue caused by invasive helminthes. Neutrophils are rapidly recruited in response to invasive helminthes. Eosinophils migrate to the site of infection where they release mediators, help in tissue remodeling, and assist neutrophils to kill the organism. ${ }^{43} \mathrm{IgE}$ is also very important. It forms immune complexes with the organisms that are then eliminated by macrophages.

\section{Chronic pulmonary inflammation}

Chronic inflammation occurs when resolution of acute inflammation is incomplete. Chronic inflammatory responses clear necrotic debris and apoptotic cells from acute inflammation; defend against and prevent the spread of persistent infections; and heal and repair the lung tissue damage. The major cells involved are macrophages and lymphocytes. Cytokines are produced by a variety of immune and nonimmune cells.
The production of these cytokines can dictate the extent and type of the inflammatory response. In chronic lung inflammation, profibrotic and immunoregulatory Th2 cytokines dominate. Chemokines play a pivotal role in regulating cell trafficking, angiogenesis, and the inflammatory response. They mediate neutrophil infiltration into the lung parenchyma and pleural space by binding to receptors on neutrophils, lymphocytes, monocytes, and dendritic cells. ${ }^{44,45}$ In mice, inoculation of the airways with Pseudomonas leads to persistent release of chemokines and time-dependent neutrophil influx. ${ }^{46}$ In interstitial pulmonary fibrosis (IPF), chemokine (IL-8) is significantly elevated and correlates with the presence of neutrophils in bronchoalveolar lavage fluid. As mentioned above, apoptosis plays an important role in chronic lung inflammation. During chronic inflammation, abnormal function of inducer or suppressor genes decreases apoptosis of immune cells. This leads to prolongation of inflammatory cell infiltration of the lungs.

Chronic airway inflammation is characteristic in both asthma and COPD, yet there are marked differences in the inflammatory cells involved. Airway eosinophils is

Table I Mechanisms in different types of infection

\begin{tabular}{|c|c|c|c|}
\hline & Response & Examples & \\
\hline Viruses & $\begin{array}{l}\text { PRRs recognize PAMPs } \rightarrow \text { NF-KB activation } \rightarrow \uparrow \text { synthesis } \\
\text { of antiviral type I IFNs }(\alpha, \beta) \text { and inflammatory cytokines } \\
\text { (TNF- } \alpha, \text { MCPI, IL-6, } 8, I 2)^{36} \\
\text { Primary infection: } \\
\text { CD8+ T cells clearing up the infection }{ }^{37} \\
\text { Secondary infection: } \\
\text { I) Recruitment of circulating memoryT cells (CD8+, CD4+) } \\
\text { (antigen nonspecific; IFN- } \gamma \text { mechanism) } \\
\text { 2) Antigen-specific T cells produced by proliferation } \\
\text { of quiescent central memory T cells (CD8+) in BALT }{ }^{68}\end{array}$ & $\begin{array}{l}\text { ssRNA viruses: } \\
\text { I) Influenza A: } \\
\text { 2) RSV: } \\
\text { dsDNA viruses } \\
\text { I) Adenovirus: } \\
\text { 2) HSV: }\end{array}$ & $\begin{array}{l}\text { TLR3 }^{69} \text { and TLR7 } \\
\text { TLR4 } \\
\text { CDI } \\
\text { CDS }^{72} \rightarrow \text { IFN, IL-6, TNF- } \alpha \text { synthesis } \\
\text { TLR2 }^{73}{ }^{7 L R} 9^{74}\end{array}$ \\
\hline Bacteria & $\begin{array}{l}\text { PRRs (TLR2 for Gm+ peptidoglycan;TLR4 for } \mathrm{Gm} \text { - LPS) } \\
\text { on APCs recognize PAMPs } \rightarrow \text { NF- } \mathrm{KB} \text { activation } \rightarrow \text { TNF- } \alpha \text {, } \\
\mathrm{IL}-1,8,{ }^{24} \rightarrow \text { neutrophil chemotaxis } \rightarrow \text { phagocytosis } \rightarrow \\
\text { resolution }\end{array}$ & $\begin{array}{l}\text { Staphylococcus aureus } \\
\text { Pseudomonas aeruginosa } \\
\text { Streptococcus pneumoniae } \\
\text { Klebsiella pneumoniae } \\
\text { Mycobacteria }\end{array}$ & $\begin{array}{l}\text { TLR2 }^{75} \\
\text { TLR5 recognizes Flagellin }{ }^{76} \text { Alveolar } \\
\text { macrophages (TLR2 less important) } \\
\text { TLR4 } \rightarrow \text { CD4+ T cells } \rightarrow \text { IL- } 17 \rightarrow \\
\text { epithelial cells } \rightarrow \text { chemokines }^{78,79} \\
\text { TLR2, } 4^{80} \rightarrow \text { cytotoxic CD } 8+\text { T cell } \\
\text { activation and IFN- } \gamma \text { production. }{ }^{81}\end{array}$ \\
\hline Parasites & $\begin{array}{l}\text { Three mechanisms involve the respiratory system: }:^{82} \\
\text { stimulation of hypersensitivity during life cycle } \\
\text { direct parenchymal or pleural invasion migration from } \\
\text { infected organs } \\
\text { Parasite specific-lgE form immune complexes which are } \\
\text { removed by macrophages }{ }^{82} \text { Protozoa vary in structure and } \\
\text { bioche-mistry } \rightarrow \text { distinct immune responses. Helminths } \rightarrow \\
\text { Th2 response and alternate macrophage activation }{ }^{83} \text { Major: } \\
\text { eosinophils, basophils, mast cells Minor: neutrophils }{ }^{43}\end{array}$ & $\begin{array}{l}\text { I) Protozoa: } \\
\text { Leishmania } \\
\text { Plasmodium } \\
\text { 2) Helminths: } \\
\text { Schistosoma }\end{array}$ & $\begin{array}{l}\text { TLR }^{84} \\
\text { TLR2, } \\
\text { produce IFN- }{ }^{38} \rightarrow \text { NK cells, NKT cells to } \\
\text { Parasite eggs } \rightarrow \text { granulomatous } \\
\text { response via TLR } 2,3^{82}\end{array}$ \\
\hline
\end{tabular}

Abbreviations: APCs, antigen presenting cells; BALT, bronchial-associated lymphoid tissues; dsDNA, double-stranded DNA; HSV, herpes simplex virus; IFN, interferon; MCPI, monocyte chemoattractant protein I; NK cells, natural killer cells; PAMPs, pathogen-associated molecular patterns; PRRs, pattern recognition receptors; RSV, respiratory syncytial virus; ssRNA, single-stranded RNA;TLR, Toll-like receptors. 
prominent in asthma, but not in COPD except during acute exacerbations. ${ }^{47,48}$ Apoptosis is inversely correlated with the clinical severity of asthma. Asthmatics show more submucosal "nonapoptotic" eosinophils than patients with chronic bronchitis or normal subjects. Bronchial biopsy specimens from asthmatic subjects reveal a higher infiltration of eosinophils expressing anti apoptotic genes (bcl-2) than those expressing pro-apoptotic oncogenes (p53). ${ }^{49}$ Decreased $\mathrm{T}$ cell apoptosis in asthma may lead to its increased number. CD4+ $\mathrm{T}$ cells are more evident in asthma, whereas CD8+ T cells are predominant in COPD.${ }^{50}$ Moreover, CD8+ T cells are higher in smokers than asthmatics. ${ }^{51,52}$ In smokers, the severity of airflow limitation correlates with the number of neutrophils, macrophages, and NK lymphocytes in bronchoalveloar lavage fluid. ${ }^{51}$ Inflammation in asthma is only in the airways, but in COPD, inflammation extends from the peripheral airways down to the lung parenchyma.

Chronic bronchitis is characterized by airflow obstruction, mucus hypersecretion, and inflammation throughout the lungs. Neutrophils predominate in the airway lumen, although mononuclear cells, macrophages, CD8+ T cells and $B$ cells infiltrate the larger airway walls. ${ }^{53}$ Plausibly, the severity of airway inflammation can be related to the severity of the disease ${ }^{51}$ and is a better pathologic marker of chronic bronchitis than submucosal gland hypertrophy.

Th2 response is involved in chronic fibroproliferative disorders. Suppression of Th1 response or exaggerated Th2 response can lead to IPF. ${ }^{54}$ Interstitial lung diseases are

Table 2 Pathology and immune mechanisms in some common respiratory diseases

\begin{tabular}{|c|c|c|c|c|}
\hline & Pathophysiology & Pathology & Cells & Mediators \\
\hline \multicolumn{5}{|l|}{ Acute } \\
\hline Pneumonia & $\begin{array}{l}\text { Parenchymal } \\
\text { inflammation } \\
\text { Lobar/patchy } \\
\text { consolidation }\end{array}$ & $\begin{array}{l}\text { Viral, bacterial, parasitic } \\
\text { Invasion } \rightarrow \text { recognition } \rightarrow \\
\text { Inflammatory amplification } \rightarrow \\
\text { phagocytosis } \rightarrow \text { resolution }\end{array}$ & $\begin{array}{l}\text { APC, }{ }^{34} \text { neutrophil, eosinophil } \\
\text { (parasites) } \\
\text { Macrophage (mycobacteria) } \\
\text { ThI/Th2 response }\end{array}$ & $\begin{array}{l}\text { IL-8,TNF- } \alpha, \text { NETs }{ }^{4} \\
\text { IL-I } \beta\end{array}$ \\
\hline ARDS/ALI & $\begin{array}{l}\mathrm{PaO}_{2} / \mathrm{FiO}_{2} \leq 200(\leq 300 \mathrm{ALI}) \\
\mathrm{PCWP} \leq 18 \mathrm{mmHg} \\
\text { Bilateral infiltrates }\end{array}$ & $\begin{array}{l}\text { Sepsis, trauma, aspiration } \\
\text { Early phase: } \uparrow \text { capillary } \\
\text { permeability } \\
\text { alveolar edema and necrosis } \\
\downarrow \text { surfactant: alveolar collapse } \\
\text { Late phase: fibrosis }\end{array}$ & $\begin{array}{l}\text { Neutrophil }^{86} \\
\text { Macrophage }^{87} \\
\text { Type I and II Pneumocytes } \\
\text { Fibroblast, Endothelial cell }\end{array}$ & $\begin{array}{l}\text { Lipid mediators, } \\
\text { Proteases, } \\
\text { NF- } \kappa B \text {, Growth } \\
\text { factors }^{89} \\
\text { IL-I } \beta, \text { TNF- }^{90}\end{array}$ \\
\hline \multicolumn{5}{|l|}{ Chronic } \\
\hline COPD & $\begin{array}{l}\uparrow T L C, R V, \downarrow V C, F^{\prime} V_{1} / F V C \\
\downarrow D L C O\end{array}$ & $\begin{array}{l}\text { Alveolar apoptosis }{ }^{91} \\
\text { Poor phagocytosis } \\
\text { of apoptotic } \\
\text { neutrophils } \rightarrow \text { necrosis } \rightarrow \uparrow N E \\
\text { release } \\
\downarrow \text { VEGF: }{ }^{92} \text { Chronic } \\
\text { parenchymal and } \\
\text { airway inflammation }\end{array}$ & $\begin{array}{l}\text { Macrophage } \\
\text { Neutrophil } \\
\text { CD8+T cell } \\
\text { Airway epithelial cell }\end{array}$ & $\begin{array}{l}\text { MMPI } 2,8,9 \text {, cathepsin } \\
\text { S,L,G }{ }^{93} \\
\text { NE, IFN- } \gamma, \text { MIG }^{94} \\
\text { TGF- } \beta, \text { EGF, PDGF }\end{array}$ \\
\hline Asthma & $\begin{array}{l}\uparrow \mathrm{FEV}_{1}>12 \% / 200 \mathrm{ml} \\
\text { after BD } \\
\downarrow \mathrm{FEV}_{1} / \mathrm{FVC}\end{array}$ & $\begin{array}{l}\text { Airway inflammation }{ }^{96} \\
\text { Fibrosis and SMC hyperplasia } \\
\downarrow \text { tolerogenic immune } \\
\text { response }\end{array}$ & $\begin{array}{l}\text { Eosinophil, }{ }^{97} \text { Mast Cell, } \\
\text { Neutrophil } \\
\text { Macrophage, DC,Airway SMC } \\
\text { Epithelial cell, Fibroblast }{ }^{99} \\
\text { CD4+T cells, }{ }^{100} \text { Basophil }^{101}\end{array}$ & $\begin{array}{l}\downarrow \text { IL-I0, }{ }^{102} \text { TGF- } \beta^{103} \\
\uparrow I L-I 7^{104} \text { and IL-4, 5, } \\
9,13^{15}\end{array}$ \\
\hline IPF & $\begin{array}{l}\downarrow \mathrm{FEV}_{1}, \mathrm{FVC}, \mathrm{TLC}, \mathrm{RV}, \mathrm{DLCO} \\
\leftrightarrow \mathrm{FEV}_{\mathrm{I}} / \mathrm{FVC}\end{array}$ & $\begin{array}{l}\text { Epithelial } \rightarrow \text { mesenchymal } \\
\text { transition }^{105} \\
\text { Injury } \rightarrow \text { mediator release: } \\
\text { fibrosis } \\
\uparrow{ }^{106} \\
\text { angiogenesis } \\
\text { Damaged basement } \\
\text { membrane }^{107}\end{array}$ & $\begin{array}{l}\text { Fibroblast } \\
\text { Airway epithelial cell } \\
\text { Type II pnemocyte }\end{array}$ & $\begin{array}{l}\text { IL-8, TNF- } \alpha, \text { TGF- } \beta^{108,109} \\
\text { IL-4, } 5,13^{110, I I I}\end{array}$ \\
\hline
\end{tabular}

Abbreviations: ALI, Acute lung injury; APC, antigen presenting cells; ARDS, Acute respiratory distress syndrome; BD, Bronchodilator; COPD, Chronic obstructive pulmonary disease; DC, Dendritic cell; DLCO, Diffusing capacity of lung for Carbon monoxide; EGF, Endothelial growth factor; FEV , Forced expiratory volume in I sec; FiO, Fraction of inspired oxygen; FVC, Forced vital capacity; IFN- $\gamma$, Interferon gamma; IL, Interleukin; MIG, Monokine induced by gamma interferon; MMP, Matrix metalloproteinases; NE, Neutrophil elastase; NETs, Neutrophil extracellular traps; NF- $\kappa \beta$, Nuclear factor kappa beta; $\mathrm{PaO}_{2}$, Partial pressure of arterial oxygen; PCWP, Pulmonary capillary wedge pressure; PDGF, Platelet derived growth factor; RV, Residual volume; SMC, Smooth muscle cell; TGF- $\beta$, Transforming growth factor beta;TLC,Total lung capacity; TNF- $\alpha$, Tumor necrosis factor alpha;Treg, Regulatory T cell; VC,Vital capacity; VEGF, Vascular endothelial growth factor. 
characterized by proliferation of fibroblasts and production of cytokines, chemokines, and glycosaminoglycans. These cytokines mediate the generation of tissue collagenase, gelatinase, and $\mathrm{PGE}_{2}$, which augment extracellular collagen and fibrinous matrix degradation. IL- $1 \alpha$ and IL- $1 \beta$ stimulate production of type I and III collagen from fibroblasts and type IV collagen from epithelial cells. Moreover, production of $\mathrm{PGE}_{2}$ inhibits fibroblast proliferation.

Th1 primarily involves granulomatous inflammation. Sarcoidosis is the best known of these, although tuberculosis and hypersensitivity pneumonitis are also important. ${ }^{55,56}$ Th2 drives eosinophilic granualomatous diseases, like ChurgStrauss vasculitis. ${ }^{57}$ Although the clinical presentation of these diseases may be different, the inflammatory processes possess a similar propagation of events in the pathogenesis of their development.

Recently, GITR (glucocorticoid-induced TNF receptorrelated protein) was found to be important in acute as well as chronic inflammation, and is closely associated with the development of pulmonary fibrosis. Neutrophil infiltration, pro-inflammatory cytokines, and toxic oxygen species are decreased in the pleural fluid in GITR-/- pleurisy mice, ${ }^{58}$ and neutrophils are decreased in the bronchoalveolar lavage fluid of GITR-/- bleomycin-induced pulmonary fibrosis mice. Moreover, lung histology also showed less fibrosis in GITR-/-mice. ${ }^{58}$

\section{Regulation of lung inflammation}

The lung provides a huge surface for gas exchange and pathogen contact. While a forceful innate immune response, such as inflammation, is needed to fight off the harmful invaders, effective regulation to suppress the inflammatory processes and limit inflammation-induced damage is also necessary to maintain homeostasis. Such regulatory mechanisms are in place to protect lung function. For example, activation of TLRs may suppress Th1- and Th2- mediated lung inflammation, thus providing negative feedback to prevent excessive lung inflammation. ${ }^{59}$ In addition, cytokines produced by inflammatory cells (IL-10 $0^{60}$ and TGF- $\beta^{61}$ ) can down regulate inflammatory cytokine production and inflammatory response. The lungs provide organ-specific regulatory strategies to prevent excessive inflammation during microbial invasion. For example, Type II epithelial cells in the lung communicate with alveolar macrophages, providing tonic inhibitory effects through TGF- $\beta$ to limit potential adaptive immune-induced lung inflammation. ${ }^{1}$ Recent evidence indicates that neural immune interaction may play an important role in controlling inflammation in a variety of diseases. ${ }^{62}$ Such control involves the peripheral and central nervous systems to regulate the body's reaction. Sensory neurons in the airways may provide a sensing mechanism to detect the inflammatory intensity in the lung for lung-brain communication. Indeed, sensory neurons in the lung are activated during acute lung injury. ${ }^{63}$ In addition, pro-inflammatory cytokines and mediators, and TLR ligands can stimulate airway sensory neurons, ${ }^{64}$ which may initiate a reflex to suppress production of pro-inflammatory cytokines. ${ }^{65}$ These negative feedback regulatory mechanisms are important in control of inflammatory intensity. On the other hand, activation of sensory afferents may release neuropeptides, which can induce neurogenic inflammation to intensify the inflammatory response. ${ }^{66,67}$

\section{Concluding remarks}

Inflammation is an important feature of many pulmonary diseases such as pneumonia, ARDS, asthma, and COPD. Varied and disparate strategies have been adopted to intervene in pulmonary immune responses. In addition to looking at the cytokines, cytokine receptors, and cell-surface molecules, cellular signal transduction and gene activation have been targeted for therapy. It is apparent that to understand the mechanism of upcoming future modalities of treatment, the physician should have a basic understanding of the underlying cellular mechanisms of inflammation.

\section{Acknowledgments}

This work was partly supported by a grant from NIH HL58727.

\section{References}

1. Oliveira ES, Hancock JT, Hermes-Lima M, et al. Implications of dealing with airborne substances and reactive oxygen species: what mammalian lungs, animals, and plants have to say? Integ Comp Biol. 2007;47:578-591.

2. Adler KB, Fischer BM, Wright DT, Cohn LA, Becker S. Interactions between respiratory epithelial cells and cytokines: relationships to lung inflammation. Ann N Y Acad Sci. 1994;725:128-145.

3. Kuroki Y, Takahashi M, Nishitani C. Pulmonary collectins in innate immunity of the lung. Cell Microbiol. 2007;9:1871-1879.

4. Kaisho T, Akira S. Toll-like receptor function and signaling. J Allergy Clin Immunol. 2006;117:979-987.

5. Nittoh T, Fujimori H, Kozumi Y, Ishihara K, Mue S, Ohuchi K. Effects of glucocorticoids on apoptosis of infiltrated eosinophils and neutrophils in rats. Eur J Pharmacol. 1998;354:73-81.

6. Fadok VA, Bratton DL, Konowal A, Freed PW, Westcott JY, Henson PM. Macrophages that have ingested apoptotic cells in vitro inhibit proinflammatory cytokine production through autocrine/ paracrine mechanisms involving TGF-beta, PGE2, and PAF. J Clin Invest. 1998;101:890-898.

7. Lipscomb MF, Bice DE, Lyons CR, Schuyler MR, Wilkes D. The regulation of pulmonary immunity. Adv Immunol. 1995;59:369-455. 
8. Nakata K, Gotoh H, Watanabe J, et al. Augmented proliferation of human alveolar macrophages after allogeneic bone marrow transplantation. Blood. 1999;93:667-673.

9. Bender AT, Ostenson CL, Wang EH, Beavo JA. Selective up-regulation of PDE1B2 upon monocyte-to-macrophage differentiation. Proc Natl Acad Sci U S A. 2005;102:497-502.

10. Burns AR, Smith CW, Walker DC. Unique structural features that influence neutrophil emigration into the lung. Physiol Rev. 2003;83:309-336.

11. Yazdanbakhsh M, Kremsner PG, van RR. Allergy, parasites, and the hygiene hypothesis. Science. 2002;296:490-494.

12. Yokoyama WM. Natural killer cell immune responses. Immunol Res. 2005;32:317-325.

13. Brigl M, Bry L, Kent SC, Gumperz JE, Brenner MB. Mechanism of CD1d-restricted natural killer $\mathrm{T}$ cell activation during microbial infection. Nat Immunol. 2003;4:1230-1237.

14. Prussin C, Metcalfe DD. 5. IgE, mast cells, basophils, and eosinophils. J Allergy Clin Immunol. 2006;117(2 Suppl Mini-Primer):S450-S456.

15. Kariyawasam HH, Robinson DS. The role of eosinophils in airway tissue remodelling in asthma. Curr Opin Immunol. 2007;19:681-686.

16. Suratt BT, Parsons PE. Mechanisms of acute lung injury/acute respiratory distress syndrome. Clin Chest Med. 2006;27:579-589.

17. Toossi Z, Hirsch CS, Hamilton BD, Knuth CK, Friedlander MA, Rich EA. Decreased production of TGF-beta 1 by human alveolar macrophages compared with blood monocytes. J Immunol. 1996;156:3461-3468.

18. Moore SA, Strieter RM, Rolfe MW, Standiford TJ, Burdick MD, Kunkel SL. Expression and regulation of human alveolar macrophagederived interleukin-1 receptor antagonist. Am J Respir Cell Mol Biol. 1992;6:569-575.

19. Ding L, Linsley PS, Huang LY, Germain RN, Shevach EM. IL-10 inhibits macrophage costimulatory activity by selectively inhibiting the up-regulation of B7 expression. J Immunol. 1993;151:1224-1234.

20. Holgate ST. Pathogenesis of asthma. Clin Exp Allergy. 2008;38:872-897.

21. Sarir H, Henricks PA, van Houwelingen AH, Nijkamp FP, Folkerts G Cells, mediators and Toll-like receptors in COPD. Eur J Pharmacol. 2008;585:346-353.

22. Suter PM, Suter S, Girardin E, Roux-Lombard P, Grau GE, Dayer JM. High bronchoalveolar levels of tumor necrosis factor and its inhibitors, interleukin-1, interferon, and elastase, in patients with adult respiratory distress syndrome after trauma, shock, or sepsis. Am Rev Respir Dis. 1992;145:1016-1022.

23. Armstrong L, Millar AB. Relative production of tumour necrosis factor alpha and interleukin 10 in adult respiratory distress syndrome. Thorax. 1997;52:442-446.

24. Stockley RA. Lung infections. 1. Role of bacteria in the pathogenesis and progression of acute and chronic lung infection. Thorax. 1998;53:58-62.

25. Wilson R, Pitt T, Taylor G, et al. Pyocyanin and 1-hydroxyphenazine produced by Pseudomonas aeruginosa inhibit the beating of human respiratory cilia in vitro. $J$ Clin Invest. 1987;79:221-229.

26. Menendez R, Torres A. Treatment failure in community-acquired pneumonia. Chest. 2007;132:1348-1355.

27. Shaw MH, Reimer T, Kim YG, Nunez G. NOD-like receptors (NLRs): bona fide intracellular microbial sensors. Curr Opin Immunol. 2008;20:377-382.

28. Sutterwala FS, Ogura Y, Flavell RA. The inflammasome in pathogen recognition and inflammation. J Leukoc Biol. 2007;82:259-264.

29. Khair OA, Devalia JL, Abdelaziz MM, Sapsford RJ, Tarraf H, Davies RJ. Effect of Haemophilus influenzae endotoxin on the synthesis of IL-6, IL-8, TNF-alpha and expression of ICAM-1 in cultured human bronchial epithelial cells. Eur Respir J. 1994;7:2109-2116.

30. Wardlaw A. Leucocyte adhesion to endothelium. Clin Exp Allergy 1990;20:619-626.

31. Takahashi GW, Andrews DF, III, Lilly MB, Singer JW, Alderson MR. Effect of granulocyte-macrophage colony-stimulating factor and interleukin-3 on interleukin-8 production by human neutrophils and monocytes. Blood. 1993;81:357-364.
32. Nakamura H, Yoshimura K, McElvaney NG, Crystal RG. Neutrophil elastase in respiratory epithelial lining fluid of individuals with cystic fibrosis induces interleukin-8 gene expression in a human bronchial epithelial cell line. J Clin Invest. 1992;89:1478-1484.

33. Gordon S. The macrophage: past, present and future. Eur J Immunol. 2007;37(Suppl 1):S9-17.

34. Mizgerd JP. Acute lower respiratory tract infection. $N$ Engl J Med. 2008;358:716-727.

35. Matute-Bello G, Liles WC, Radella F, et al. Neutrophil apoptosis in the acute respiratory distress syndrome. Am J Respir Crit Care Med. 1997;156:1969-1977.

36. Wang JP, Kurt-Jones EA, Finberg RW. Innate immunity to respiratory viruses. Cell Microbiol. 2007;9:1641-1646.

37. Woodland DL. Cell-mediated immunity to respiratory virus infections. Curr Opin Immunol. 2003;15:430-435.

38. Coban C, Ishii KJ, Uematsu S, et al. Pathological role of Toll-like receptor signaling in cerebral malaria. Int Immunol. 2007;19:67-79.

39. Kropf $\mathrm{P}$, Freudenberg N, Kalis $\mathrm{C}$, et al. Infection of $\mathrm{C} 57 \mathrm{BL} / 10 \mathrm{ScCr}$ and $\mathrm{C} 57 \mathrm{BL} / 10 \mathrm{ScNCr}$ mice with Leishmania major reveals a role for Toll-like receptor 4 in the control of parasite replication. J Leukoc Biol. 2004; 76:48-57.

40. rsic-Arsenijevic V, Dzamic A, Mitrovic S, Radonjic I, Kranjcic-Zec I. [Characteristics of the immune response in protozoan infections]. Med Pregl. 2003;56:557-563.

41. Liew FY, O'Donnell CA. Immunology of leishmaniasis. Adv Parasitol. 1993;32:161-259.

42. McGuinness DH, Dehal PK, Pleass RJ. Pattern recognition molecules and innate immunity to parasites. Trends Parasitol. 2003;19: 312-319.

43. Anthony RM, Rutitzky LI, Urban JF Jr, Stadecker MJ, Gause WC. Protective immune mechanisms in helminth infection. Nat Rev Immunol. 2007;7:975-987.

44. Zlotnik A, Yoshie O. Chemokines: a new classification system and their role in immunity. Immunity. 2000;12:121-127.

45. Frevert CW, Farone A, Danaee H, Paulauskis JD, Kobzik L. Functional characterization of rat chemokine macrophage inflammatory protein-2. Inflammation. 1995;19:133-142.

46. Tsai WC, Strieter RM, Mehrad B, Newstead MW, Zeng X, Standiford TJ CXC chemokine receptor CXCR2 is essential for protective innate host response in murine Pseudomonas aeruginosa pneumonia. Infect Immun. 2000;68:4289-4296

47. Barnes PJ, Shapiro SD, Pauwels RA. Chronic obstructive pulmonary disease: molecular and cellular mechanisms. Eur Respir J. 2003;22:672-688.

48. Fabbri LM, Romagnoli M, Corbetta L, et al. Differences in airway inflammation in patients with fixed airflow obstruction due to asthma or chronic obstructive pulmonary disease. Am J Respir Crit Care Med. 2003; $167: 418-424$.

49. Vignola AM, Chanez P, Chiappara G, et al. Evaluation of apoptosis of eosinophils, macrophages, and T lymphocytes in mucosal biopsy specimens of patients with asthma and chronic bronchitis. $J$ Allergy Clin Immunol. 1999;103:563-573.

50. Sutherland ER, Martin RJ. Airway inflammation in chronic obstructive pulmonary disease: comparisons with asthma. J Allergy Clin Immunol. 2003;112:819-827.

51. Di SA, Capelli A, Lusuardi M, et al. Severity of airflow limitation is associated with severity of airway inflammation in smokers. Am J Respir Crit Care Med. 1998;158:1277-1285.

52. O'Shaughnessy TC, Ansari TW, Barnes NC, Jeffery PK. Inflammation in bronchial biopsies of subjects with chronic bronchitis: inverse relationship of CD8+ $\mathrm{T}$ lymphocytes with $\mathrm{FEV}_{1}$. Am J Respir Crit Care Med. 1997;155:852-857.

53. Szilasi M, Dolinay T, Nemes Z, Strausz J. Pathology of chronic obstructive pulmonary disease. Pathol Oncol Res. 2006;12:52-60.

54. Strieter RM, Keane MP. Innate immunity dictates cytokine polarization relevant to the development of pulmonary fibrosis. $J$ Clin Invest. 2004;114:165-168. 
55. Gerke AK, Hunninghake G. The immunology of sarcoidosis. Clin Chest Med. 2008;29:379-390, vii.

56. Hernandez C, Cetner AS, Jordan JE, Puangsuvan SN, Robinson JK. Tuberculosis in the age of biologic therapy. J Am Acad Dermatol. 2008;59:363-380.

57. Hellmich B, Csernok E, Gross WL. Proinflammatory cytokines and autoimmunity in Churg-Strauss syndrome. Ann N Y Acad Sci. 2005;1051:121-131.

58. Nocentini G, Cuzzocrea S, Bianchini R, Mazzon E, Riccardi C. Modulation of acute and chronic inflammation of the lung by GITR and its ligand. Ann N Y Acad Sci. 2007;1107:380-391.

59. Hayashi T, Beck L, Rossetto C, et al. Inhibition of experimental asthma by indoleamine 2,3-dioxygenase. J Clin Invest. 2004;114:270-279.

60. Raychaudhuri B, Fisher CJ, Farver CF, et al. Interleukin 10 (IL-10)mediated inhibition of inflammatory cytokine production by human alveolar macrophages. Cytokine. 2000;12:1348-1355.

61. Pittet JF, Griffiths MJ, Geiser T, et al. TGF-beta is a critical mediator of acute lung injury. $J$ Clin Invest. 2001;107:1537-1544.

62. Otmishi P, Gordon J, El-Oshar S, et al. Neuroimmune interaction in inflammatory diseases. Clin Med Circ Respir Pulm Med. 2008;2:35-44.

63. Lin S, Walker J, Xu L, Gozal D, Yu J. Respiratory: Behaviours of pulmonary sensory receptors during development of acute lung injury in the rabbit. Exp Physiol. 2007;92:749-755.

64. Yu J, Lin S, Zhang J, Otmishi P, Guardiola JJ. Airway nociceptors activated by pro-inflammatory cytokines. Respir Physiol Neurobiol. 2007;156:116-119.

65. Tracey KJ. The inflammatory reflex. Nature. 2002;420:853-859.

66. Bozic CR, Lu B, Hopken UE, Gerard C, Gerard NP. Neurogenic amplification of immune complex inflammation. Science. 1996;273:1722-1725.

67. Veronesi B, Carter JD, Devlin RB, Simon SA, Oortgiesen M. Neuropeptides and capsaicin stimulate the release of inflammatory cytokines in a human bronchial epithelial cell line. Neuropeptides. 1999;33:447-456.

68. Kohlmeier JE, Miller SC, Smith J, et al. The chemokine receptor CCR5 plays a key role in the early memory $\mathrm{CD} 8+\mathrm{T}$ cell response to respiratory virus infections. Immunity. 2008;29:101-113.

69. Guillot L, Le GR, Bloch S, et al. Involvement of toll-like receptor 3 in the immune response of lung epithelial cells to double-stranded RNA and influenza A virus. $J$ Biol Chem. 2005;280:5571-5580.

70. Diebold SS, Kaisho T, Hemmi H, Akira S, Reis e Sousa C. Innate antiviral responses by means of TLR7-mediated recognition of singlestranded RNA. Science. 2004;303:1529-1531.

71. Kurt-Jones EA, Popova L, Kwinn L, et al. Pattern recognition receptors TLR4 and CD14 mediate response to respiratory syncytial virus. Nat Immunol. 2000;1:398-401.

72. Nociari M, Ocheretina O, Schoggins JW, Falck-Pedersen E. Sensing infection by adenovirus: Toll-like receptor-independent viral DNA recognition signals activation of the interferon regulatory factor 3 master regulator. J Virol. 2007;81:4145-4157.

73. Kurt-Jones EA, Chan M, Zhou S, et al. Herpes simplex virus 1 interaction with Toll-like receptor 2 contributes to lethal encephalitis. Proc Natl Acad Sci U S A. 2004;101:1315-1320.

74. Krug A, Luker GD, Barchet W, Leib DA, Akira S, Colonna M. Herpes simplex virus type 1 activates murine natural interferon-producing cells through toll-like receptor 9. Blood. 2004;103:1433-1437.

75. Yoshimura A, Lien E, Ingalls RR, Tuomanen E, Dziarski R, Golenbock D. Cutting edge: recognition of Gram-positive bacterial cell wall components by the innate immune system occurs via Toll-like receptor 2. J Immunol. 1999;163:1-5.

76. Zhang Z, Louboutin JP, Weiner DJ, Goldberg JB, Wilson JM. Human airway epithelial cells sense Pseudomonas aeruginosa infection via recognition of flagellin by Toll-like receptor 5. Infect Immun. 2005;73:7151-7160.

77. Xu F, Droemann D, Rupp J, et al. Modulation of the inflammatory response to $S$. pneumoniae in a model of acute lung tissue infection. Am J Respir Cell Mol Biol. 2008;39:522-529.
78. Happel KI, Zheng M, Young E, et al. Cutting edge: roles of Toll-like receptor 4 and IL-23 in IL-17 expression in response to Klebsiella pneumoniae infection. J Immunol. 2003;170:4432-4436.

79. Ye P, Rodriguez FH, Kanaly S, et al. Requirement of interleukin 17 receptor signaling for lung CXC chemokine and granulocyte colony-stimulating factor expression, neutrophil recruitment, and host defense. J Exp Med. 2001;194:519-527.

80. Means TK, Jones BW, Schromm AB, et al. Differential effects of a Toll-like receptor antagonist on Mycobacterium tuberculosis-induced macrophage responses. J Immunol. 2001;166:4074-4082.

81. Vesosky B, Flaherty DK, Turner J. Th1 cytokines facilitate CD8-T-cell-mediated early resistance to infection with Mycobacterium tuberculosis in old mice. Infect Immun. 2006;74:3314-3324.

82. Fischer GB, Sarria EE, Leite AJ, de Britto MC. Parasitic lung infection and the paediatric lung. Paediatr Respir Rev. 2008;9:57-65.

83. Reyes JL, Terrazas LI. The divergent roles of alternatively activated macrophages in helminthic infections. Parasite Immunol. 2007;29:609-619.

84. Kropf P, Freudenberg MA, Modolell M, et al. Toll-like receptor 4 contributes to efficient control of infection with the protozoan parasite Leishmania major. Infect Immun. 2004;72:1920-1928.

85. D'Ombrain MC, Hansen DS, Simpson KM, Schofield L. Gammadelta$\mathrm{T}$ cells expressing NK receptors predominate over NK cells and conventional T cells in the innate IFN-gamma response to Plasmodium falciparum malaria. Eur J Immunol. 2007;37:1864-1873.

86. Ware LB, Matthay MA. The acute respiratory distress syndrome. N Engl J Med. 2000;342:1334-1349.

87. Dong L, Wang S, Chen M, Li H, Bi W. The activation of macrophage and upregulation of CD40 costimulatory molecule in lipopolysaccharide-induced acute lung injury. $J$ Biomed Biotechnol. 2008;2008:852571.

88. Gropper MA, Wiener-Kronish J. The epithelium in acute lung injury/acute respiratory distress syndrome. Curr Opin Crit Care. 2008;14:11-15.

89. Luh SP, Chiang CH. Acute lung injury/acute respiratory distress syndrome (ALI/ARDS): the mechanism, present strategies and future perspectives of therapies. J Zhejiang Univ Sci B. 2007;8:60-69.

90. Gropper MA, Wiener-Kronish J. The epithelium in acute lung injury/acute respiratory distress syndrome. Curr Opin Crit Care. 2008;14:11-15.

91. Segura-Valdez L, Pardo A, Gaxiola M, Uhal BD, Becerril C, Selman M. Upregulation of gelatinases A and B, collagenases 1 and 2, and increased parenchymal cell death in COPD. Chest. 2000;117:684-694.

92. Kanazawa H, Asai K, Hirata K, Yoshikawa J. Possible effects of vascular endothelial growth factor in the pathogenesis of chronic obstructive pulmonary disease. Am J Med. 2003;114:354-358.

93. Shapiro SD. Proteolysis in the lung. Eur Respir J Suppl. $2003 ; 44: 30$ s- 2 s.

94. Grumelli S, Corry DB, Song LZ, et al. An immune basis for lung parenchymal destruction in chronic obstructive pulmonary disease and emphysema. PLoS Med. 2004;1:e8.

95. Sharafkhaneh A, Hanania NA, Kim V. Pathogenesis of emphysema: from the bench to the bedside. Proc Am Thorac Soc. 2008;5:475-477.

96. De Monchy JG, Kauffman HF, Venge P, et al. Bronchoalveolar eosinophilia during allergen-induced late asthmatic reactions. Am Rev Respir Dis. 1985;131:373-376.

97. Bousquet J, Jeffery PK, Busse WW, Johnson M, Vignola AM. Asthma. From bronchoconstriction to airways inflammation and remodeling. Am J Respir Crit Care Med. 2000;161:1720-1745.

98. Koh YY, Dupuis R, Pollice M, Albertine KH, Fish JE, Peters SP. Neutrophils recruited to the lungs of humans by segmental antigen challenge display a reduced chemotactic response to leukotriene B4. Am J Respir Cell Mol Biol. 1993;8:493-499.

99. Doucet C, Brouty-Boye D, Pottin-Clemenceau C, Canonica GW, Jasmin C, Azzarone B. Interleukin (IL) 4 and IL-13 act on human lung fibroblasts. Implication in asthma. J Clin Invest. 1998;101:2129-2139. 
100. Robinson D, Hamid Q, Bentley A, Ying S, Kay AB, Durham SR. Activation of CD4+ T cells, increased TH2-type cytokine mRNA expression, and eosinophil recruitment in bronchoalveolar lavage after allergen inhalation challenge in patients with atopic asthma. J Allergy Clin Immunol. 1993;92:313-324.

101. Guo CB, Liu MC, Galli SJ, Bochner BS, Kagey-Sobotka A, Lichtenstein LM. Identification of IgE-bearing cells in the late-phase response to antigen in the lung as basophils. Am J Respir Cell Mol Biol. 1994;10:384-390.

102. Hawrylowicz CM. Regulatory T cells and IL-10 in allergic inflammation. J Exp Med. 2005;202:1459-1463.

103. Scherf W, Burdach S, Hansen G. Reduced expression of transforming growth factor beta 1 exacerbates pathology in an experimental asthma model. Eur J Immunol. 2005;35:198-206.

104. Schnyder-Candrian S, Togbe D, Couillin I, et al. Interleukin-17 is a negative regulator of established allergic asthma. J Exp Med. 2006;203:2715-2725.

105. Willis BC, Liebler JM, Luby-Phelps K, et al. Induction of epithelialmesenchymal transition in alveolar epithelial cells by transforming growth factor-beta1: potential role in idiopathic pulmonary fibrosis. Am J Pathol. 2005;166:1321-1332.
106. Noble PW, Homer RJ. Idiopathic pulmonary fibrosis: new insights into pathogenesis. Clin Chest Med. 2004;25:749-758, vii.

107. Katzenstein AL. Pathogenesis of "fibrosis" in interstitial pneumonia: an electron microscopic study. Hum Pathol. 1985;16:1015-1024.

108. Strieter RM, Gomperts BN, Keane MP. The role of CXC chemokines in pulmonary fibrosis. $J$ Clin Invest. 2007;117:549-556.

109. Zhang Y, Lee TC, Guillemin B, Yu MC, Rom WN. Enhanced IL-1 beta and tumor necrosis factor-alpha release and messenger RNA expression in macrophages from idiopathic pulmonary fibrosis or after asbestos exposure. J Immunol. 1993;150:4188-4196.

110. Ando M, Miyazaki E, Fukami T, Kumamoto T, Tsuda T. Interleukin4-producing cells in idiopathic pulmonary fibrosis: an immunohistochemical study. Respirology. 1999;4:383-391.

111. Lee CG, Homer RJ, Zhu Z, et al. Interleukin-13 induces tissue fibrosis by selectively stimulating and activating transforming growth factor beta(1). J Exp Med. 2001;194:809-821. 
